\title{
ASSESSMENT OF THE QUALITY OF SERVICE IN THE CATERING INDUSTRY AS AN IMPORTANT DETERMINANT IN ESCALATING THE LEVEL OF CONSUMER CONFIDENCE
}

\section{AGNIESZKA GÓRKA-CHOWANIEC}

Academy of Physical Education, Department of Sport and Tourism Management, POLAND

e-mail: agnieszkagorka@interia.eu

RECEIVED

ACCEPTED

JEL

CLASSIFICATION

KEYWORDS

ABSTRACT
16 August 2017

15 December 2017

L22, L23, L83, M21, O32

quality in services, catering industry, consumer confidence

Internationalization of modern enterprises in service industry, turbulent environment in which they operate and constant expansion of the competition in the catering industry force enterprises to seek more innovative ways to remain on the market. Quality is the key factor in the development strategy of entities in the catering industry, the objective of which is to achieve long-term competitive advantage, both on domestic and foreign catering market. Enterprises, applying consumer-oriented approach as the key factor in their development strategy, seek to shape an ideal level of services provided which will help to distinguish their services from among similar competitive services. The aim of such actions is, first of all, to satisfy the customer providing the appropriate level of service. The aim of this study is to try to identify the impact of service quality on the level of consumer confidence in the catering industry and to identify factors determining the essence of the quality of catering services, in the opinion of respondents. The basis of the analysis was results of the author's surveys carried out on a sample of 300 consumers from hotel restaurants (four-star hotels) located in the area of Silesian region.

Quality is our best assurance of customer allegiance, our strongest defense against foreign competition, and the only path to sustained growth and earnings John Welch - CEO of General Electric

\section{Introduction}

Dynamic changes observed in the recent years on the Polish market of catering services, first of all analyzing its supply side, stem from changes in attitudes and customer's purchasing intentions in the food industry. The quality of food consumed away from home or nutrition habits form an important determinant affecting the consumer's behaviour within the analyzed field. Currently, the consumer chooses food of appropriate quality which is often 
assessed on the basis of three features: healthiness (safety, nutritional value, calorific value and dietetic value), sensory value (visual appearance, smell, consistency, structure and taste) and availability (durability and recognition of the kind); (Cieślik, Stachura, Topolska, 2010, p. 556; Grębowiec, 2010; Kmiołek, 2010; Kowalska, 2010; Markovic, Raspor, Šegaric, 2010, p. 181). Poles use catering services more often and spent more money on it. ${ }^{1}$ According to data provided by Central Statistical Office and contained in the "Small Statistical Yearbook of Poland 2016", in 2016 the number of food establishments rose by 1481 , as compared to the previous year. ${ }^{2}$ Restaurant facilities in hotel industry which, currently, operate in increasing competition environment more frequently seek innovative ways to remain on the market. These hotels which provide, in their offer, complex catering business may use this aspect of their market operation to improve the general quality of provided services, in the opinion of their customers, in order to increase their competitive position on the industry market. One of the manifestations of such approach is the adoption of customer-based orientation by the enterprise through the satisfaction which is the effect of proper satisfied needs. One of the ways to achieve this state is to focus the attention of the hotel on the expansion of proquality activities, including catering service, the effect of which is the general improvement of the quality of provided services. The achievement, by a given entity, of a proper (satisfactory to the customer) quality of provided services requires proper identification of factors which forms the essence of identified quality of catering services in the opinion of customers. Proper identification of quality determinants, in the opinion of hotel's guests, may form a basis for the entity to determine an integrated quality management system of provided services, at the same time, raising the chance to acquire a group of steady and loyal customers. Bearing in mind the importance of quality of services in the catering industry as an important determinant in escalating the level of consumer confidence, the author, in the present study, attempted to identify the impact of quality of service on the level of consumer confidence and identify a group of factors which, first of all, determine the essence of quality of catering services in the opinion of respondents.

\section{Catering service in light of source literature}

Starting deliberations on the essence of services in the catering industry, it seems appropriate to present the classic definition of services. Seen from this angle, the service is perceived as activities or advantage which may be offered by one of the parties to another, intangible in nature and not leading to the acquisition of any form of ownership (Kotler, Armstrong, Saunders, Wong, 2002, p. 41). On the other hand, K. Rogoziński defines the service through the relation system and defines it in the following manner: "Service is understood as the undertaken order, intentional provision of work and/or benefits. It enriches personal characteristics or usability volume of goods which are possessed by the recipient" (Rogoziński, 2000, p. 36). H. Rudecki identifies catering service as a set of particular activities, including in particular manufacturing activities, the essence of which is to "transform" food products for consumption and commercial purposes which contain the sale of food products, highlighting the need to provide the condition to consume them on the site (1974). Other authors present similar approach with regard to the essence of catering services and define catering service as a set of activities, the aim of which is to achieve a certain added value in the opinion of the customer in the form of, e.g. set of dishes, proper conditions for their

\footnotetext{
${ }^{1}$ Catering market in Poland, Report 2016. Retrieved from: horecanet.pl (26.06.2017).

${ }^{2}$ Concise Statistical Yearbook of Poland 2016. Warszawa: GUS. Retrieved from: stat.gov.pl (16.06.2017).
} 
consumption or provision of certain entertainments and additional services (Szajna, Ławniczak, Ziaja, 2015, p. 57). Therefore, catering services constitute for the customer certain kind of benefits in several key fields:

- physical (helps to satisfy hunger and thirst),

- economic (helps to purchase, within a set budget, dishes and beverages of proper quality and with the possibility to save financial resources),

- psychological (high quality of services is observed as an important determinant raising self-assessment and social status of consumers),

- social (when a customer uses catering service it is possible for him to strengthen or initiate new social contacts).

Górska-Warsewicz, Mikulska and Sawicka note thatthe provision of catering services takes place under concrete and specific conditions, underlining the key importance of the quality level of internal and external infrastructure of premises, where the services are provided (2014). According to the presented division of catering industry in one of literature studies, catering service market can be divided into: individual catering services, systemic catering services, special catering services market (Grzesińska, 2012, p. 11).

A. Kmiołek presents the catering service on the basis of activities carried out to satisfy certain needs, mainly nutrition by producing and serving ready-made dishes (2013). A basis in the provision of services in the catering industry is production-service operation which consists of operating mass caterers (restaurants, cafes) (Konarzewska, 2016). Catering industry constituting business of open and production-service nature covers with its competencies many catering entities providing broadly understood services of nutrition character (Duda, Krzywda, 2013 , p. 87). The essence of catering services is determined by the set of activities, the basis of which is to produce dishes and beverages, sell these products and other commercial goods combined with consumer service, expanded with cultural, entertainment or recreational service package (Milewska, Prączko, Stasiak, 2010, p. 350). Definition presented above clearly signals the complex nature of addressed issues. J. Duda and S. Krzywda, when defining the essence of catering service, divide it into basic services (nutrition), additional services, e.g. within culturalentertainment field satisfying social needs and complementary services (e.g. catering, transport and informative) the offer of which is varied and adjusted to the recipient's needs (2014). W. Reich, the notion of services in the catering industry can be referred to the activities which consist of offering dishes and beverages to the customer, including provision of entertainment services (Sala, 2004, p. 49). The notion of service is very often understood as all kinds of economic activity of intangible character which are determined by the high level of interactivity between the recipient and service provider. Taking into account the above mentioned considerations, catering service may be defined by production-service activities of entities in order to satisfy disclosed consumer needs, the basis of which is interdisciplinary and specific culinary knowledge combined with the art of consumer service.

\section{Identification of quality in catering industry sepvices}

Considering the quality interpretation of American Control Association we may conclude that the quality is the set of certain characteristics of product/service which determine their abilities to satisfy specific recipients' needs (Horbaczewski, 2006). W.B. Martin proposes similar definition referring to the quality of services, defining quality as the ability of a given enterprise to satisfy needs and expectations of, both internal and external customers, including technical and functional elements (2006). In turn, C. Armistead and G. Clark distinguished the factors determining the quality of services on hard and soft. Among the hard authors they distinguished: time, physical 
factors, flexibility of the service. Among the soft ones they distinguished: style, security, "controllability" (influence of recipients on the process of creating a service), (Armistead, Clark, 1994). According to marketing philosophy, service is characterized by the certain level of quality if its execution meets or goes beyond the expectations of its customers (Czubała, Jonas, Smoleń, Wiktor, 2012, p. 142). Source literature differentiates the level of consumers' expectations regarding services, defining them with the use of four phases (Illy et al., 1995; Czubała et al., 2012):

- ideal service - the quality of service is higher than the consumers' expectations, is a basis to create values and satisfy customers (Toruński, 2013, p. 80),

- desired service - standard of service which is expected by the consumer,

- satisfactory service (acceptable) - service which should be provided for the agreed price,

- minimal service - service which should present the lowest level of service, acceptable by the customer.

In the process of service provision, there is always a comparison of expectations with real experience of the consumer, who may also asses the service as non-acceptable level of quality which may significantly decrease his satisfaction and lead to failure to use the service in the future.

Quality in the aspect of operation of service enterprises is a strategic notion which determines the level of satisfaction and consumer confidence. While analyzing the notion of quality we need to take into account several perspectives. The first area determines the category of quality in the opinion of consumers, as a recipient of catering service, and quality according to managers who create such service. In case of the consumer, quality is his subjective evaluation, including the expectations, hierarchy of values or benefits providing by the specific service. In the opinion of managers, quality of services is a reference of specific characteristics of offered services to the specific pattern which was adopted by the enterprise as a reference point in defined quality standards.

The second perspective allows us to divide quality into technical quality focusing on the operational processes and may be enhanced by the application of modern technological solutions; and functional quality focusing on the relations between the recipient and the service provider. In the operation of service enterprises, including catering industry, we may observe that these enterprises, focusing on the quality in practice, easier acquire and maintain market advantage and acquire growing group of steady and loyal customers, acquiring long-term market success (Stoma, 2012, p. 9). Parasuraman and others identify factors affecting the level of quality of service by their categorization with regard to ten criteria (1985):

- material criterion (external infrastructure of the entity, premises equipment, where services are provided and the appearance and presentation of employees (Di Lucchio, 2012, pp. 252-257). According to Mruk and Sznajder, an important element of innovative solution in modern catering industry is shaping the environment and the place of dishes consumption which is understood as the so called emotional branding (2008, p. 46),

- reliability criterion (accuracy of service provision),

- sensitivity criterion (full understanding of the customer's needs, provision of assistance, provision of advice especially for those guests, who are undecided),

- competence criterion (level of personnel's expertise, knowledge resources and skills which are necessary to provide services),

- credibility criterion (shaping of quality should be constant process which build the identity of the brand, and should be understood through the reliability), 
- safety criterion (adjustment to standards shaping health quality of produced food, including among others, GHP, GMP, GLP and HACCP systems as well as ISO and TQM standards),

- availability criterion (ease of service purchase, possibility to acquire detailed information on the process of service provision and contact with the service provider),

- communication criterion (efficient flow of information, mutual and non-disturbed exchange of remarks and assumptions),

- understanding of needs and expectations of both, current and potential consumers,

- the ideal value criterion (Mattsson, 1992),

- the quality criteria for internal services (Frost, Kumar, 2000).

To sum up, currently the quality of services in catering industry is perceived as one of the major elements in competing strategy of modern enterprises. Thanks to the possibility of identification criteria which determine customers to select the service and know the ways of assessment the quality of services, entities are able to adjust their offer to the needs and expectation of loyal and steady customers as well as future recipients.

\section{Empirical material and methodology}

In order to perform the main objective of the present study which is the identification of the impact of catering service quality on the level of customers confidence and identification of factors determining the quality of catering services, the author carried out the author's survey in hotel restaurants, four-star hotels located in the area of Silesian region. From among 35 four-star hotels located in the surveyed area, the author randomly selected 20 entities in which surveys were carried out (figures for 15.03.2017; source: bip.slaskie.pl). The present study applies survey methodology with the use of direct interview questionnaire. Surveys were carried out anonymously in the period from March to May 2017 on the sample composed of 300 respondents. As a result of surveys, the author acquired 297 completely filled questionnaires and such amount was subjected to final verification in order to acquire credible results. The questionnaire which was prepared for the purpose of the present study was composed of three parts. The first part focuses on the scope of identified issues and explains their purpose. The most important part of the survey, from the point of view of the purpose of the survey, is contained in the second part and covered 10 questions concerning the quality of catering services provided in hotels and their impact on the level of confidence and loyalty of customers. The following results, due to the limit content of the text, contain only most important survey results which will help to draw synthetic conclusions with regard to assumed purpose of the present study. Third part of the questionnaire helped to identify demographic features of the surveyed respondents in the field of: sex, age, professional status and purpose of the trip).

According to the acquired data from the analysis of demographic features of respondents, the survey covered $35 \%$ of women and $65 \%$ of men. From among respondents, the most numerous group (56\%) were persons aged $32-45$, while respondents aged $46-60$ constituted 19\%. The next group (13\%) constituted persons above 60 years. The least numerous group were persons aged 18-30 identifying 12\% participation in the survey. Analyzing professional status of the surveyed population, it can be stated that the most numerous group were persons in active professional life $-77 \%$ of respondents. Retirees/pensioners constitute $19 \%$ of surveyed, while persons with the status of trainee or student constituted $4 \%$ of respondents. No persons having unemployed status participated in the survey $(0 \%)$. Analyzing the purpose of trip with regard to the analyzed area, more than three quarter $(77 \%)$ of 
surveyed persons declared professional purpose of the trip (professional), while $23 \%$ of respondents visited hotel due to private purpose.

\section{Survey results}

From among surveyed respondents, $67 \%$ indicated that when choosing the hotel as a place of accommodation draw attention to the level of provided catering services in the hotel restaurants. For the remaining $33 \%$ of surveyed persons the factor of the level of provided catering services is not important during the process of booking. The analysis of answers on next questions indicated that the most important criterion while choosing the hotel, analyzing the aspect of provided catering services, is the quality of provided dishes, such response was provided by more than one third of respondents (33\%), the next important factor, in the opinion of the respondents, was the level of service (21\%), own experience of customers (knowledge of the subject) who visited the restaurant earlier, used services and choose another purchase (19\%) as well as recommendation of the entity by friends (16\%). The least important factor, in the opinion of surveyed persons is price; such answer was provided by $11 \%$ of respondents. While analyzing factors which affect the level of catering services in hotels, own survey results indicate that varied menus, appearance of provided dishes and cleanliness of the facility constitute a criterion of quality of catering services, in the opinion of surveyed persons $(26 \%, 19 \%$ and $13 \%$, respectively). Below, the author presents detail set of acquired answers (Figure 1).

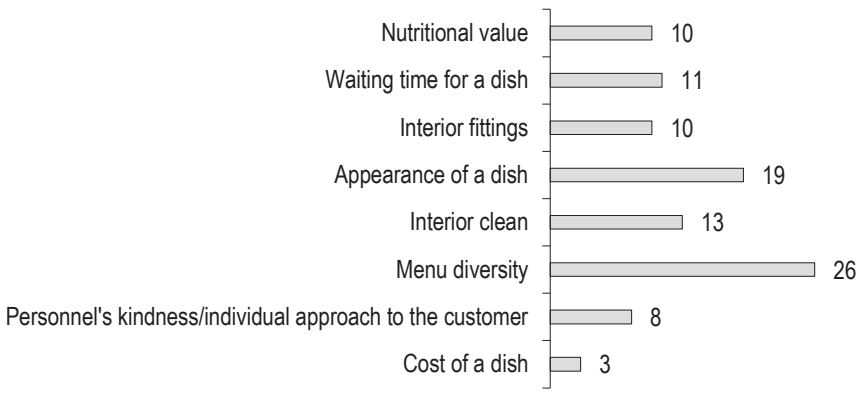

Figure 1. Factors determining the quality of catering services in hotel facilities ${ }^{3}$

Source: own study on the basis of carried our surveys.

While analyzing the factor determining re-selection of hotels restaurant as a place of catering service more than half of the respondents indicated the quality of provided dishes (51\%). Taking into account the hierarchy of answers, the next place is the level of customer service (22\% of the respondents), aesthetic and appearance of a dish (12\%) and interior design (9\%). The least important factor taking into account during re-selection of hotel restaurant in the opinion of the respondents is the price, such answer was provided by only $6 \%$ of respondents which way stem from the fact that surveys were carried out in four-star facilities which are visited by customers having more than average social status. As it is shown by results, the main factor which may raise dissatisfaction in

3 In the question concerning factors which determine the quality of catering services in hotels facilities, the respondents were asked to identify max. 3 factors which, according to them, are most important from the point of view of the examined issue. 
the opinion of the respondents during the use of catering services and result in the lack of re-visit is mainly too long time of waiting for the ordered dish, almost half of respondents provided such answer (43\%), failure to meet by the dish the description in the menu (18\%) and unsatisfactory quality of provided dishes (15\%). Below graph presents detail set of answers acquired by the author (Figure 2).

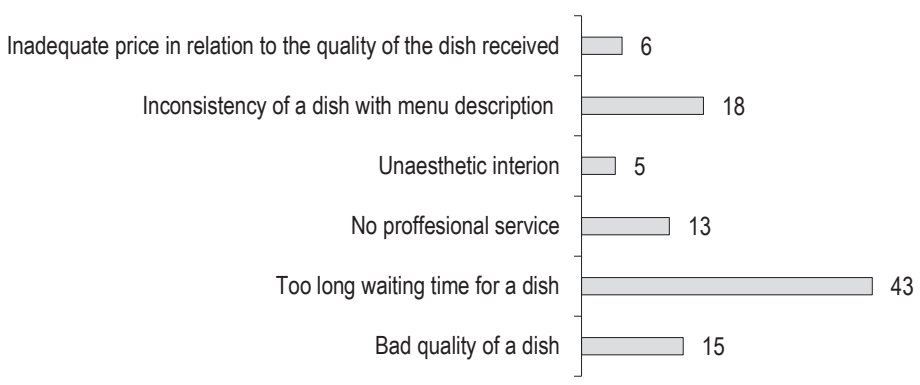

Figure 2. Factors escalating the level of dissatisfaction of customers during the use of catering services

Source: own study on the basis of carried our surveys.

While analyzing respondents' answers on the question: whether low level of the quality of provided catering services in hotel entities may affect on the number of persons who re-visit a given hotel and use accommodation services, we can observe that the majority of respondents provided the answer definitely yes $(49 \%), 33 \%$ of respondents state that the low level of provided catering services may determine decision concerning the use of accommodation services, while only one fifth of the respondents (18\%) state that the quality of provided catering services in the hotel does not affect the use of accommodation service. No respondents indicated that the quality of catering service provided in hotel entities definitely affect the consumer's decision concerning the use of accommodation service in a given facility $(0 \%)$.

\section{Conclusions}

Results of carried out surveys clearly state that, in the opinion of the respondents, the main criterion concerning selection of the hotel facility is definitely the level of provided catering services in hotel restaurant $(67 \%$ of the respondents). In the opinion of the respondents, the main determinant on the level of provided catering services is the quality of provided dishes (33\% of respondents). The main factor determining the quality of catering services is varied menu, appearance of a dish and cleanliness. The majority of respondents (in total $88 \%$ of respondents) indicated that low level of provided catering services in the hotel may affect the number of guests who want to use the accommodation services one again. To sum up, we may state that the organization of the production process, the way of its provision, smell, colour or standard of premise interior strongly affect the mood of the consumer, affect their behaviour, the level of loyalty or determine the use of services in the future (Kosicka-Gębska, Tul-Krzyszczuk, Gębski, 2015, p. 41). 


\section{Referencees}

Armistead, C., Clark, G. (1994). The "Coping” Capacity Management Strategy in Services and the Influence on Quality Performance. International Journal of Service Industry Management, 2 (5), 5-21.

Catering market in Poland, Report 2016. Retrieved from: horecanet.pl (26.06.2017).

Cieślik, E., Stachura, M., Topolska, K. (2010). Jakość usług gastronomicznych w opinii konsumentów. Bromatologia i Chemia Toksykologiczna, 4, 556 .

Concise Statistical Yearbook of Poland 2016. Warszawa: GUS. Retrieved from: stat.gov.pl (16.06.2017).

Czubała, A., Jonas, T., Smoleń, J., Wiktor, W. (2012). Marketing usług. Warszawa: Wolters Kluwer Polska.

Di Lucchio, L. (2012). Design for the Next-Food. An alternative approach of Food Design focused on social and system innovation. The Proceedings of the International Conference on Designing Food and Designing for Food, London, pp. 252-257.

Duda, J., Krzywda, S. (2013). Hotelarstwo. Vol. IV. Usługi żywieniowe w hotelarstwie. Warszawa: WSiP.

Dziadkowiec, T. (2006). Wybrane metody badania i oceny jakości usług. Zeszyty Naukowe Akademii Ekonomicznej w Krakowie, 23-35.

Frost, F.A., Kumar, M. (2000). INTSERVQUAL: An internal adaptation of the GAP model in a large service organization. Journal of Services Marketing, 5, 360-361.

Górska-Warsewicz, H., Sawicka, B., Mikulska, T. (2014). Działalność gospodarcza w gastronomii. Warszawa: WSiP.

Grębowiec, M. (2010). Czynniki warunkujące jakość oraz ich wpływ na podejmowanie decyzji nabywczych na rynku gastronomicznym. Ekonomika i Organizacja Gospodarki Żywnościowej, 80, 117.

Grzesińska, W. (2012). Technologiczne projektowanie zakładów gastronomicznych. Warszawa: SGGW.

Hamrol, A., Mantura, W. (2005). Zarządzanie jakościa. Teoria i praktyka. Warszawa: Wydawnictwo Naukowe PWN.

Horbaczewski, D. (2006). Filozoficzne źródła współczesnego pojmowania jakości. Problemy jakości, 10, 10-12.

Illy, A., Viani, R. (1995). Espresso Coffee. London-San Diego: Academic Press Limited.

Janiak, D. (2004). Dobra praktyka produkcyjna i dobra praktyka higieniczna w gastronomii z elementami HACCP, SIT NOT SPOŻ. Warszawa.

Kmiołek, A. (2010). Technologia gastronomiczna. Warszawa: WSiP.

Konarzewska, M. (2016). Technologia gastronomiczna z towaroznawstwem. Warszawa: WSiP.

Kosicka-Gębska, M., Tul-Krzyszczuk, A., Gębski, J. (2011). Handel detaliczny żywnością w Polsce (ed. 2). Warszawa: Wydawnictwo SGGW.

Kotler, Ph., Armstrong, G., Saunders, J., Wong, V. (2002). Marketing. Podręcznik europejski. Warszawa: PWE.

Kowalska, A. (2010). Jakość $i$ konkurencyjność w rolnictwie ekologicznym. Warszawa: Difin.

Markovic, S., Raspor, S., Šegaric, K. (2010). Does restaurant performance meet customers' expectations? An assessment of restaurant service quality, using a modified Dineserv approach. Tourism and Hospitality Management, 16, 181.

Martin, W.B. (2006). Zarządzanie jakością obsługi w restauracjach i hotelach. Kraków: Wolters Kluwer Polska.

Mattsson, J. (1992). A service quality model based on ideal value standard. International Journal of Service Industry Management, 3 , 28.

Milewska, M., Prączko, A., Stasiak A. (2010). Gastronomia. Warszawa: PWE.

Mruk, H., Sznajder, M. (2008). Neuromarketing. Poznań: Wyd. UP.

Myszewski, J.M. (2009). Po prostu jakość. Podręcznik zarządzania jakością. Warszawa: WAiP.

Parasuraman, V., Zeithaml, L.B. (1985). A Conceptual Model of Service Quality and Its Implications for Future Research. American Marketing Association, The Journal of Marketing, 4 (49), 41-50.

Popławski, M. (2013). Nowoczesne koncepcje zarzadzania. Teoria i praktyka. Wrocław: Wydawnictwo WSOWL.

Rogoziński, K. (2000). Usługi rynkowe. Poznań: Wydawnictwo Akademii Ekonomicznej.

Rudecki, H. (1974). Próba usystematyzowania niektórych pojęć w gastronomii. Przegląd Gastronomiczny, 5, 56.

Sala, J. (2004). Marketing w gastronomii. Warszawa: PWE.

Stoma, M. (2012). Modele i metody pomiaru jakości usług. Lublin: Q\&R Polska.

Szajna, R., Ławniczak, D., Ziaja, A. (2015). Usługi kelnerskie. Warszawa: WSiP, p. 57. 
Szostak, D. (2006). Obsługa turysty w obiektach bazy noclegowej i żywieniowej. In: B. Meyer (ed.), Obsługa ruchu turystycznego. Warszawa: Wydawnictwo Naukowe PWN.

Toruński, J. (2013). Zarządzanie jakością w przedsiębiorstwie usługowym. Zeszyty naukowe Uniwersytetu Przyrodniczo-Humanistycznego w Siedlcach, 80.

Wawak, S. (2011). Zarzązanie jakościa. Podstawy, systemy i narzędzia. Gliwice: Wydawnictwo Helion.

Zymonik, Z., Hamrol, A., Grudowski, P. (2013). Zarzadzanie jakościa i bezpieczeństwem. Warszawa: PWE.

Cite this anticle aS: Górka-Chowaniec, A. (2018). Assessment of the quality of service in the catering industry as an important determinant in escalating the level of consumer confidence. European Journal of Service Management, 1 (25), 99-107. DOI: 10.18276/ ejsm.2018.25-12. 